\title{
Non-invasive prenatal diagnosis using fetal cells in maternal blood
}

\author{
Y-M D Lo
}

\section{Introduction}

One of the goals of modern genetics is the development of safe and reliable prenatal diagnostic tests which do not constitute a risk to the fetus. Currently, the safety of available methods is limited by the need to obtain fetal tissue for analysis by invasive means, such as amniocentesis and chorionic villus sampling (CVS), which present a finite risk to the fetus. One potentially non-invasive approach for obtaining fetal material for diagnosis is the use of fetal cells in maternal circulation. This article summarises some of the major recent developments in this rapidly expanding field.

\section{Historical perspective}

In 1893 Schmorl first suggested that nucleated fetal cells may be found in maternal circulation and that portions of the villous system of the placenta can become detached and pass into the maternal circulation. ${ }^{1} \mathrm{He}$ based his conclusions on the finding of multinucleate cytoplasmic fragments, which he regarded as placental in origin, in the pulmonary vessels of women who had died in eclampsia. These observations were confirmed by other investigators who found morphological evidence of syncytiotrophoblasts in lung sections of $43.6 \%$ (96 of 220 ) of women dying during pregnancy. ${ }^{2}$ Other workers studied buffy coated smears made from maternal blood taken from broad ligament veins, ovarian veins, and the inferior vena cava and were able to detect cells with morphological syncytiotrophoblast features in a proportion of the women. ${ }^{3}$

These studies, though of historical interest, are of little relevance to the use of fetal cells for non-invasive prenatal diagnosis as, in these studies, fetal cells were only found following tissue or blood sampling through invasive means. A number of investigators have attempted to confirm the existence of fetal cells in maternal peripheral blood using a variety of methods, including cytogenetic analysis, ${ }^{4}$ quinacrine staining, ${ }^{5}$ culture, ${ }^{6}$ and flow cytometry. ${ }^{78}$ However, many of these methods are either non-specific or not reproducible by other groups. These issues have been discussed in a number of recent reviews and will not be discussed in this paper. ${ }^{910}$

The development of molecular biology has provided many new and highly sensitive tools for detecting and confirming the existence of fetal cells in maternal blood. The specificity of molecular biological techniques constitutes an important step forward as the previous criteria for identifying a given cell as of fetal origin were either subjective (morphology) or non-specific (quinacrine staining) or not easily applicable to the detection of a minority cell population (cytogenetics).

One group attempted to use Southern blotting using a $\mathrm{Y}$ chromosomal probe to detect $Y$ specific sequences from peripheral blood DNA extracted from women carrying a male fetus. ${ }^{11}$ Their assay was able to detect a fetomaternal ratio of 1 in 5000 but they were unable to detect any evidence of fetal specific $\mathrm{Y}$ sequences in any of their samples. These results were important because all the previous data using morphological, quinacrine staining, cytogenetic, and flow cytometric criteria estimated a feto-maternal ratio of much higher than 1 in $5000(0.02 \%)$, thus suggesting that early workers might have erroneously scored many maternal cells as being of fetal origin.

Further evidence which disputed the conclusions of some of the earlier studies came from analysis of fluorescence activated cell sorter (FACS) enriched cells using molecular probes which showed that in some of these studies, the alleged "fetal cells" were actually of maternal origin. ${ }^{12} 13$

\section{The polymerase chain reaction}

Further development in molecular genetics has recently rekindled excitement in the field of non-invasive prenatal diagnosis by providing an extremely powerful technique, the polymerase chain reaction (PCR).$^{14}$ PCR is an elegant technique for amplifying nucleic acids in vitro. By repeated thermal denaturation, primer annealing and polymerase extension, PCR can amplify a single target DNA molecule to quantities which can be detected easily. This exquisite sensitivity and specificity make it an ideal tool for detecting a rare target such as the elusive fetal cell in maternal blood. ${ }^{15}$

In 1989 PCR was successfully used to detect fetal DNA in maternal circulation using a nested amplification procedure. ${ }^{16}$ In this study nested PCR was used to detect a highly repetitive $\mathrm{Y}$ target at the DYZ1 locus in peripheral blood DNA from 19 pregnant women. All 12 pregnant women whose samples gave rise to a positive $\mathrm{Y}$ signal later gave birth to boys, while all seven whose samples were negative gave birth to girls. This provides the first conclusive molecular
Correspondence to: Dr Y-M D Lo

Accepted for publication 31 August 1994 
Table 1 Amplification of fetal derived Y chromosomal sequences from maternal peripheral blood

\begin{tabular}{|c|c|c|c|c|}
\hline Authors & $\begin{array}{l}\text { Gestational age } \\
\text { (weeks) }\end{array}$ & $P C R$ target & $\begin{array}{l}\text { Amplification } \\
\text { regimen }\end{array}$ & Accuracy \\
\hline $\begin{array}{l}\text { Suzumori et a }{ }^{17} \\
\text { Merel et al }{ }^{18} \\
\text { Hamada } \text { et }^{19}{ }^{19}\end{array}$ & $\begin{array}{l}17-20 \\
13 \\
7-40\end{array}$ & $\begin{array}{l}\text { DYZ1 } \\
\text { DYZ1 } \\
\text { DYZ1 }\end{array}$ & $\begin{array}{l}40+20 \\
40+17 \\
40+15-40 \\
\quad \text { (semiquantitative) }\end{array}$ & $\begin{array}{l}85 \%(85 / 100) \\
68 \%(65 / 95) \\
80 \%(40 / 50)\end{array}$ \\
\hline $\begin{array}{l}\text { Kao et al }{ }^{20} \\
\text { Gänshirt- } \\
\quad \text { Ahlert } \text { et } a l^{21}\end{array}$ & $40^{8-12}$ & $\begin{array}{l}\text { ZFY } \\
\text { SRY }\end{array}$ & $\begin{array}{l}32+40 \\
30 \text { cycles } \\
\text { followed by } \\
\text { Southern } \\
\text { blotting }\end{array}$ & $\begin{array}{l}92 \%(33 / 36) \\
43 \%(6 / 14)^{\star}\end{array}$ \\
\hline $\begin{array}{l}\text { Adkinson et al }{ }^{22} \\
\text { Wachtel et al }{ }^{23} \\
\text { Chakravarty et al }{ }^{24}\end{array}$ & $\begin{array}{r}11-16 \\
10-21 \\
6-18\end{array}$ & $\begin{array}{l}\text { DYZ1 } \\
\text { DYS14 } \\
\text { DYS14 }\end{array}$ & $\begin{array}{l}30+30 \\
40+25 \\
40+25\end{array}$ & $\begin{array}{l}96 \%(48 / 50) \\
65 \%(15 / 23) \\
95 \%(190 / 200)\end{array}$ \\
\hline
\end{tabular}

^ Only women bearing male fetuses were studied.

evidence that fetal cells do indeed circulate in maternal blood and that genetic information regarding the fetus can be obtained from analysing maternal peripheral blood.

Amplification of fetal $\mathrm{Y}$ chromosomal sequences from maternal blood has now been confirmed by a number of groups. ${ }^{17-25}$ In all these reports fetal Y chromosomal DNA was detected by PCR from maternal peripheral blood which has not been previously enriched for fetal cells. A number of $\mathrm{Y}$ chromosomal targets have been used in these reports, including DYZ1, ${ }^{17-19} 22$ DYS14, ${ }^{19}{ }^{23-25} \mathrm{ZFY}^{20}$ and SRY. ${ }^{21}$ Data from our group ${ }^{1625}$ and Hamada et $a l^{19}$ suggest that the high copy number of the DYZ1 locus offers a higher sensitivity than the low copy number DYS14 locus. The study by Suzumori et al ${ }^{17}$ is interesting as it clearly demonstrates that some $\mathrm{Y}$ targets-for example, the amelogenin genes, which are present both on the $\mathrm{X}$ and $\mathrm{Y}$ chromosomes and produce PCR products of different sizes, are not suitable for amplification because of the low sensitivity and underlines the principle that the amplification system used for fetal cell detection should be as fetal specific as possible. However, it is also of interest to note that some investigators have consistently obtained better results than others-for example, Kao et $a l^{20}$ reported an overall accuracy of $92 \%$. There is clearly a need for investigators from different groups to compare their laboratory protocols and practice in an attempt to improve overall results. The results from these various reports are summarised in table 1 .

Most of the studies mentioned in the previous paragraph used the nested PCR protocol as initially developed for the DYZ1 locus. ${ }^{16}$ While this procedure has been very useful in improving the sensitivity and specificity of the amplification step, it is relatively labour intensive and prone to contamination. Recent

Table 2 Detection of unique fetal derived DNA sequences from maternal blood

\begin{tabular}{|c|c|c|}
\hline Authors & Fetal target & Effect of maternal background \\
\hline Lo et $a^{162532}$ & $\begin{array}{l}\text { Y chromosome } \\
\text { sequence }\end{array}$ & $\mathrm{XX}$ thus no amplification \\
\hline & Rhesus D gene & $\begin{array}{l}\text { Rhesus D negative and so does not possess } \\
\text { the gene }\end{array}$ \\
\hline Camaschella et al ${ }^{31}$ & Lepore-Boston gene & $\begin{array}{l}\text { PCR will not amplify across the normal } \delta \text { - } \\
\text { and } \beta \text {-globin genes due to presence of } \\
\text { seven kilobases of intervening DNA }\end{array}$ \\
\hline
\end{tabular}

development of an alternative amplification regime using the Hot Start process ${ }^{2627}$ has enabled the achievement of single molecule sensitivity without using nested PCR. This process has been shown to effectively obviate the need for nested PCR and may prove to be the method of choice in future studies involving the amplification of $\mathrm{Y}$ specific sequences from maternal blood. ${ }^{28}$ Furthermore, the inclusion of an anti-carryover contamination measure involving the incorporation of dUTP and uracil-N-glycosylase treatment prior to amplification has improved the robustness of the resulting amplification system..$^{28}$

As the fetal cells in maternal circulation are surrounded by a great excess of maternal cells, the use of the PCR on maternal blood samples not previously enriched for fetal cells is limited to the detection of fetal derived, paternally inherited sequences. Apart from Y chromosome sequences of a male fetus, two autosomal fetal genes have also been successfully detected from unsorted maternal peripheral blood. The first is the detection of fetal rhesus D gene from the peripheral blood of rhesus negative women. ${ }^{29}{ }^{30}$ In this example the rhesus negative mother does not possess the rhesus $\mathrm{D}$ gene and thus the system is directly analogous to that of the $\mathrm{Y}$ chromosome system. The non-invasive prenatal determination of fetal rhesus $D$ status has potential implications for the management of previously sensitised rhesus negative women with a partner heterozygous for the rhesus $\mathrm{D}$ gene. In this situation no further prenatal diagnostic and therapeutic procedure is necessary if the fetus can be shown to be rhesus negative.

The other system is the detection of a paternally inherited haemoglobin LeporeBoston gene from maternal peripheral blood. ${ }^{31}$ The Lepore-Boston gene is caused by the fusion of the $5^{\prime}$ half of the $\delta$-globin gene and the $3^{\prime}$ half of the $\beta$-globin gene, together with a seven kilobase deletion between the two fusion partners. The information on these two examples is summarised in table 2.

However, these three examples (detection of the Y chromosome, rhesus D, and LeporeBoston sequences) represent special cases as most fetal genes which are the targets of prenatal diagnosis have maternal counterparts-for example, the $\beta$-globin gene and the cystic fibrosis transmembrane conductance regulator gene. Any PCR system which is to be used in these situations has to be much more specific than those mentioned in the previous paragraph. In these circumstances the detection system has to be able to detect the relatively small number of nucleotide differences which distinguish the fetal from the maternal sequences. This issue will be discussed in more detail later on in this paper. Assuming that this can be done, PCR may be of use in two categories of autosomal disorders namely, autosomal dominant disorders in families where the father carries the mutation and autosomal recessive disorders in which the father and mother carry different 
AUTOSOMAL DOMINANT

Father

Mother

Father

Mother

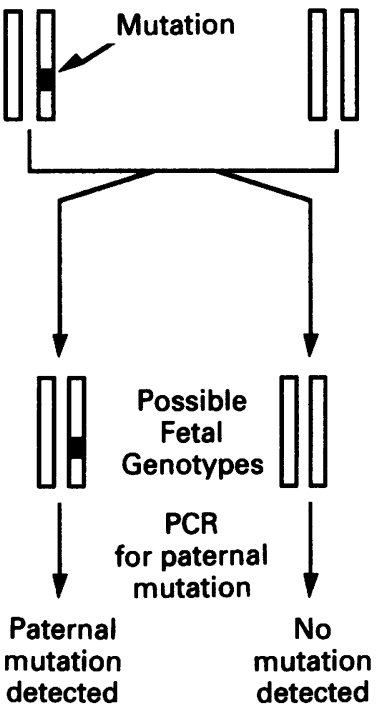

AUTOSOMAL RECESSIVE
Paternal mutation
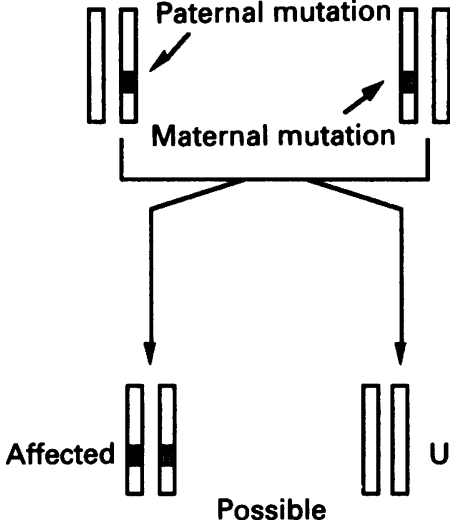$$
\text { Fetal }
$$

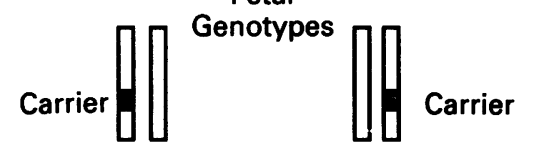

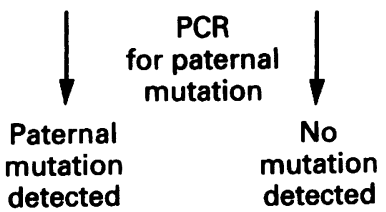

Application of PCR for the detection of paternally inherited mutations in autosomal genes from maternal peripheral blood. In this analysis either no or a relatively low enrichment of fetal cells is assumed and PCR is used for direct mutation detection. For autosomal dominant disorders, the detection of a paternally inherited mutation indicates an affected fetus. For autosomal recessive disorders, the father and the mother must carry different mutations. Autosomal recessive disorders in which more than one mutation is found include cystic fibrosis and $\beta$-thalassaemia. The detection of a paternally inherited mutation from maternal peripheral blood indicates that there is a 50\% chance that the fetus is homozygous for the disease causing mutations. Apart from direct mutation detection, PCR can also be used to detect polymorphic markers linked to disease causing genes.

mutations (figure). In certain families and in disorders in which the mutant gene has not been identified, but in which linked DNA markers are known, the method can be modified to detect paternally inherited DNA polymorphisms. Provided that the families have previously affected offspring and that the paternal chromosomes can be distinguished from one another and from the maternal ones, useful information concerning the fetal genotype can be obtained.

Detection of autosomal fetal targets for which the mother and the fetus both possess a copy of the sequence is a challenging problem. Theoretically, there are two ways to approach this problem. The first involves the use of a system which will amplify both the fetal and maternal sequences, which are then distinguished from one other by a subsequent analytical step-for example, electrophoresis. The main problem with this strategy is that the PCR plateau of $3-5 \mathrm{pmol}^{33}$ is then shared between the fetal and maternal PCR products. As the maternal template at the start of the PCR is in great excess compared with the fetal one, most of the resulting PCR product is of maternal origin. In other words the amplification factor for the fetal sequence is limited. The best studied examples of systems in which the majority and minority populations are co-amplified may be found in the literature on post bone marrow transplantation chimaerism in which the typical sensitivity of these assays ranges from $0 \cdot 1-1 \%$, far below the level required to detect the rare fetal cell in maternal blood. ${ }^{1534}$

The second approach involves the design of amplification systems which will specifically amplify the fetal sequence, while remaining refractory to the related, but not identical, maternal sequence. The amplification refractory mutation system (ARMS) ${ }^{26}$ is a type of PCR which is capable of achieving this aim. ARMS enables PCR to be discriminatory down to the single nucleotide level. It is based on the principle that the specificity of the PCR is conferred by the $3^{\prime}$ end of the primers. Thus, if there is a $3^{\prime}$ terminal mismatch between a PCR primer and the DNA target, the amplification efficiency will be greatly reduced. When using ARMS to detect paternally inherited polymorphisms of the fetus from maternal peripheral blood, ARMS primers are designed such that the last base of the primer matches the paternal allele but has a $3^{\prime}$ terminal mismatch with the maternal alleles. It is important to realise that ARMS only confers relative selectivity for the detection of fetal specific sequence. In other words the mismatched allele will also be amplified, albeit with reduced efficiency compared with the matched one. Hence, one is faced with a dilemma when applying ARMS to the detection of extremely small amount of fetal genetic material from maternal blood; the small quantities of fetal material require the use of a large number of PCR cycles, but the high degree of cycling means that the extent to which the mismatched reaction takes place is also increased. With further developments in ARMS technology, such as the double ARMS, ${ }^{35}$ one can achieve the goal of detecting a minority DNA population at a level of 1 in $10^{5}$ or below. Using double ARMS, a paternally inherited polymorphism in the $\beta$-globin locus was detected in maternal blood. ${ }^{36}$ This latter system may potentially be used for the diagnosis of $\beta$-thalassaemia.

\section{Fetal cell enrichment}

Although the data published so far using PCR on unenriched samples have been encouraging, it is obvious that further improvement in diagnostic accuracy is necessary before non-invasive prenatal diagnosis using fetal cells in maternal blood can be used clinically. The main obstacle to overcome is the rarity of fetal cells in maternal blood. Many investigators have explored fetal cell enrichment techniques and, so far, have concentrated on four types of fetal cells as targets for enrichment.

\section{NUCLEATED RED BLOOD CELLS}

This is by far the most encouraging candidate cell type for enrichment. This approach is first proposed by Bianchi $e t a l^{37}$ and is based on the principle that nucleated red blood cells (NRBC) constitute a significant proportion of the red blood cells in fetal blood, but are very rare in peripheral adult blood. Indeed, circu- 
lating NRBCs comprise about $10 \%$ of the red blood cells in the 11 week old fetus and $0.5 \%$ in the 19 week old fetus.

Various markers have been employed to enrich for these NRBCs. Bianchi et al ${ }^{37}$ initially flow sorted using an antibody against the transferrin receptor (CD71). Subsequently, further data have suggested that the combination of anti-CD71 with other antibodies-for example, with anti-glycophorin A antibody ${ }^{39}$ or anti-CD36 (thrombospondin receptor) ${ }^{39}$ would further improve the results. Gänshirt-Ahlert et $a l^{40}$ have explored the use of a triple-density gradient, followed by magnetic activated cell sorting (MACS) to isolate NRBCs and have claimed satisfactory results. Zheng et $\mathrm{al}^{41}$ have also reported success using MACS to deplete maternal peripheral blood of leucocytes, followed by detection of fetal erythroid cells with an antibody against fetal haemoglobin. Overall, the preliminary data on NRBCs have been encouraging but the proportion of fetal cells in the enriched samples is still low-for example, only 0.001 to $4.8 \%$ of a FACS enriched sample consists of fetal cells. ${ }^{42}$ Further improvement in this area will require more experimentation with more efficient systems for enrichment and possibly testing of more antibodies against NRBCs.

Very recently, a completely new approach has been proposed which involves the selective culture of fetal erythroid cells from maternal blood. ${ }^{43}$ This strategy uses the fact that there are more erythroid precursors in fetal than in maternal blood, and that these fetal erythroid precursors have a shorter cell cycling time and are more sensitive to exogenously added growth factors than their adult counterparts. Further experimentation may allow the isolation of pure fetal erythroid colonies from maternal blood.

\section{TROPHOBLAST CELLS}

Trophoblast cells are the obvious cell type to be investigated because of their intimate relation with the uterine vasculature. Early work using the allegedly trophoblast specific monoclonal antibody $\mathrm{H} 315^{7}$ was found to be invalid because $\mathrm{H} 315$ positive cells sorted from maternal blood were shown only to have maternal genetic markers ${ }^{13}$ and that $\mathrm{H} 315$ negative cells could adsorb the antigen in vitro. ${ }^{12}$

More recently, Mueller et $a l^{44}$ developed and screened a panel of monoclonal antibodies against placental tissues. They found five antibodies that were specific for fetal tissue, two of which were used to isolate fetal cells using immunomagnetic techniques. Following PCR amplification using $Y$ specific primers, fetal sex was correctly identified in seven of seven males and six of seven females. However, it has been unfortunate that so far the authors have not shared reagents with other workers and so their results have not been verified by an independent group as yet.

Although other antitrophoblast monoclonal antibodies have been generated by other groups, ${ }^{45}$ doubts remain regarding the specificity of these antibodies. ${ }^{9}$

\section{LYMPHOCYTES}

The presence of fetal lymphocytes in maternal blood was suggested as early as 1969 when Walknowska et $a^{4}$ performed cytogenetic analysis on phytohaemagglutinin stimulated peripheral blood lymphocyte cultures from pregnant women. Herzenberg et $a l^{8}$ used flow sorting to enrich for fetal nucleated cells using a paternally inherited HLA allele, which is present on the fetal, but not maternal, cells. They suggested that these cells were lymphocytes. However, it is equally likely that these cells are actually nucleated red cell precursors which have not yet lost their HLA class I antigens. Recently, this approach has been combined with PCR and has resulted in the successful amplification of paternal HLA alleles from the flow sorted cells. ${ }^{46}$ However, the main limitation of this approach for prenatal diagnosis is the inconvenience of having to HLA type the father and the mother before flow sorting and the fact that it is impossible to predict which of the paternal HLA alleles are inherited by the fetus.

\section{GRANULOCYTES}

Weissman et al ${ }^{47}$ have reported the detection of fetal granulocytes from maternal peripheral blood. Using density gradient centrifugation followed by non-isotopic in situ hybridisation with a $\mathrm{Y}$ specific probe, a proportion of $\mathrm{Y}$ positive cells had granulocyte morphology. However, the number of these presumed "fetal granulocytes" was unusually large (up to $0 \cdot 14 \%$ ) and the frequency of fetal cells was not consistent with other recent reports.

\section{Diagnosis of fetal chromosomal aneuploidy}

Several investigators have used either flow sorting or immunomagnetic separation followed by fluorescence in situ hybridisation (FISH) to detect aneuploid fetal cells sorted from maternal blood. ${ }^{3840489}$ As yet, the number of reported cases is very small and further work is necessary to assess the sensitivity and specificity of this approach.

\section{Biological questions regarding \\ feto-maternal cell trafficking}

Relatively little is known about the biological parameters governing the passage of fetal cells into maternal circulation. For example, it is still not known whether the existence of fetal cells in maternal circulation represents a normal physiological phenomenon present in all pregnant women or whether it is merely a consequence of random feto-maternal haemorrhage. This key issue has a direct bearing on the general applicability of prenatal diagnosis using fetal cells in maternal blood.

NUMBER OF FETAL CELLS IN MATERNAL BLOOD Data generated using PCR indicate that the frequency of fetal cells in maternal blood in most women is of the order of 1 nucleated fetal cell per $10^{5}-10^{6}$ nucleated maternal cells. 
This figure has been confirmed by data obtained using fetal cell enrichment techniques. ${ }^{38}$ Thus, Price et al ${ }^{38}$ estimated that there are between 200 and 2000 fetal nucleated red cells per $20 \mathrm{ml}$ of maternal peripheral blood. There are approximately $1.6 \times 10^{8}$ nucleated maternal cells in $20 \mathrm{ml}$ of maternal blood, resulting in a feto-maternal ratio of between 1 in 80000 and 1 in 800000 maternal cells.

There is also evidence in the literature that the frequency of fetal cells in the peripheral blood of women carrying aneuploid fetuses may, in some cases, be higher than that of women carrying euploid fetuses. In a case report Elias et al ${ }^{48}$ estimated that $74 \%$ of cells sorted from a patient carrying a trisomy 21 fetus were of fetal origin. Apart from obvious biological interest, this observation also has direct bearing in the accuracy of non-invasive prenatal testing of fetal chromosomal aneuploidies.

The optimal time during pregnancy for detecting circulating fetal cells remains unclear. PCR data reported so far indicate that fetal DNA can be detected from maternal circulation throughout pregnancy ${ }^{32}$ starting from the fourth to sixth week of gestation. 2550 However, these studies have regarded nucleated fetal cells, irrespective of cell lineage, as a single group as no cell fractionation was used in these studies. A number of workers have studied one particular fetal cell population, the NRBCs, but have so far found results which are contradictory in many respects. For example, Bianchi et $a l^{51}$ reported that NRBCs were unlikely to be present after 16 weeks of gestation and attempted to explain this by referring to the reduction in the proportion of NRBCs in the fetal circulation as pregnancy progresses. However, this effect has not been observed by others. $^{940}$ Thus, Gänshirt-Ahlert et al ${ }^{40}$ reported that NRBCs could be enriched in all three trimesters while data from the Tennessee group ${ }^{38}$ suggested that NRBCs were present from at least 10 to 18 weeks of gestation. This issue will need to be resolved by sequential sampling of a large series of pregnant women.

\section{EFFECT OF BLOOD GROUP INCOMPATIBILITY}

There has been no systematic study of the effect of $\mathrm{ABO}$ incompatibility between the mother and the fetus and the frequency of fetal cells in maternal blood. However, recent data generated through the detection of fetal rhesus $D$ sequences from rhesus $D$ negative maternal blood indicates that the number of fetal cells decrease in the presence of high levels of anti-D antibody. ${ }^{30}$

\section{PERSISTENCE OF FETAL CELIS FROM PREVIOUS} PREGNANCIES

Persistence of fetal cells from previous pregnancies is an issue which has implications for the diagnostic accuracy of tests involving fetal cells from maternal circulation. Data from our group suggest that this is unlikely to be an important phenomenon in most women at a detection sensitivity of 1 nucleated fetal cell per 300000 nucleated maternal cells. ${ }^{32}$ However, using PCR alone, it is difficult, if not impossible, to conclusively prove that this phenomenon does not exist even in a minority of women. This is because such analysis will require the study of a large number of women postpartum (for example, those who have previously delivered male babies), in which the use of PCR alone will almost certainly generate false positive results in some cases. These false positive results, if erroneously regarded as true positive, could then be interpreted as evidence for fetal cell persistence. Indeed, such interpretations have been made. ${ }^{52}$ Similarly, data suggesting that fetal cells persist from previous pregnancies have been presented by Bianchi et a ${ }^{3}$ who sorted for fetal cells using anti-CD34 and were able to detect a $\mathrm{Y}$ chromosomal signal using nested PCR from a number of women who gave birth to boys many years before. However, the number of presumed fetal derived CD34 cells is likely to be very small because, despite prior fetal cell enrichment, the $\mathrm{Y}$ signal was only detected following nested PCR, with no signal being seen after one round of PCR.

\section{RELATION TO PRE-ECLAMPSIA}

Pre-eclampsia is a syndrome that develops during pregnancy, labour, or the early puerperium. Maternal and fetal clinical symptoms and signs are secondary manifestations of the disease, but its pathogenesis remains unclear. For many years, some investigators related the primary cause to the placenta, and it is becoming more apparent that the disorder is a trophoblast dependent process. ${ }^{54}$ Many of the original morphological studies claiming the detection of trophoblasts in maternal tissue were performed on patients dying from eclampsia. ${ }^{12}$ Recently, these observations were extended by an immunocytochemical study using a monoclonal antibody against cytokeratin to label trophoblast cells in cell smears of uterine venous blood obtained at caesarean section..$^{55}$ In this study women with pre-eclampsia were found to have more trophoblast cells in uterine venous blood than women without pre-eclampsia. Further work along similar lines would therefore be of value in the understanding of the pathogenesis of this disorder.

\section{Conclusion}

In conclusion, the detection and characterisation of fetal cells in the maternal circulation is a rapidly expanding field of investigation with important implications for both prenatal diagnosis and for a better understanding of the physiology of feto-maternal interactions. It is hoped that further new concepts and technological advances will now hasten the development of this field and lead to the introduction of non-invasive prenatal diagnosis into routine clinical practice.

The author is supported by a Career Development Fellowship from the Wellcome Trust. 
1 Schmorl G. Pathologische-anatomische Untersuchungen über Puerperal-Eklampsie. Leipzig: Vogel, 1893.

2 Attwood HD, Park WW. Embolism to the lungs by trophoblast. F Obstet Gynaecol Br Cwealth 1961;68 611-7.

3 Douglas GW, Thomas L, Carr M, Cullen NM, Morris R. Trophoblast in the circulating blood during pregnancy. Am $\mathcal{F}$ Obstet Gynecol 1959;78:960-9.

4 Walknowska J, Conte FA, Grumbach MM. Practical and theoretical implications of fetal/maternal lymphocyte transfer. Lancet 1969;i:1119-22.

5 Schroder J, de la Chapelle A. Fetal lymphocytes in the maternal blood. Blood 1972;39:153-61.

6 Selypes A, Lorencz R. A noninvasive method for determination of the sex and karyotype of the fetus from the maternal blood. Hum Genet 1988;79:357-9.

7 Covone AE, Mutton D, Johnson PM, Adinolfi M Trophoblast cells in peripheral blood from pregnan women. Lancet 1984;ii:841-3.

8 Herzenberg LA, Bianchi DW, Schroder J, Cann HM, Iverson GM. Fetal cells in the blood of pregnant women: detection and enrichment by fluorescenceactivated cell sorting. Proc Natl Acad Sci USA 1979;76: activated

9 Simpson JL, Elias S. Isolating fetal cells from maternal blood: advances in prenatal diagnosis through molecular technology. $¥ A M A$ 1993;270:2357-61.

10 Lo YMD, Wainscoat JS, Fleming KA. Prenatal genetic analysis from maternal blood. Lab Medica 1991;8:25-7.

11 Gänshirt-Ahlert D, Pohlschmidt M, Gal A, Miny P, Horst J, Holzgreve W. Ratio of fetal to maternal DNA is less than 1 in 5000 at different gestational ages in maternal blood. Clin Genet 1990;38:38-43.

12 Covone AE, Kozma R, Johnson PM, Latt SA, Adinolfi $M$. Analysis of peripheral maternal blood samples for the Analysis of peripheral maternal blood samples for the presence of placenta-derived cells using Y-specific

13 Bertero MT, Camaschella C, Serra A, Bergui L, CaligarisCappio F. Circulating, trophoblast cells in pregnancy have maternal genetic markers. Prenat Diagn 1988;8: 585-90.

14 Saiki RK, Gelfand DH, Stoffel S, Scharf SJ, Higuchi R, Horn GT, et al. Primer-directed enzymatic amplification of DNA with a thermostable DNA polymerase. Science 1988;239:487-91.

15 Lo YMD. Detection of minority nucleic acid populations by PCR-a review. $\mathscr{f}$ Pathol (in press).

16 Lo YMD, Patel P, Wainscoat JS, Sampietro M, Gillmer MDG, Fleming KA. Prenatal sex determination by DNA amplification from maternal peripheral blood Lancet 1989;ii: $1363-5$.

17 Suzumori K, Adachi R, Okada S, Narukawa T, Yagami Y, Sonta $S$. Fetal cells in the maternal circulation: detec tion of Y-sequence by gene amplification. Obstet Gynecol 1992;80:150-4.

18 Merel P, Saura R, Comeau F, Grison O, Vezon G. Detection of fetal DNA in maternal blood by PCR may also lead to false negative results. Am $\mathcal{f}$ Hum Genet 1991;49(Suppl): 198 .

19 Hamada H, Arinami T, Kubo T, Hamaguchi H, Iwasak H. Fetal nucleated cells in maternal peripheral blood: frequency and relationship to gestational age. Hum Genet 1993;91:427-32.

20 Kao SM, Tang GC, Hsieh TT, Young KC, Wang HC, Pao CC. Analysis of peripheral blood of pregnan women for the presence of fetal $\mathrm{Y}$ chromosome-specific ZFY gene deoxyribonucleic acid sequences. Am $¥$ Obste Gymecol 1992;166:1013-9.

21 Gänshirt-Ahlert D, Basak N, Aidynli K, Holzgreve W. Fetal DNA in uterine vein blood. Obstet Gynecol 1992 80:601-3.

22 Adkison LR, Andrews RH, Vowell NL, Koontz WL Improved detection of fetal cells from maternal blood with polymerase chain reaction. Am $\mathcal{F}$ Obstet Gynecol 1994;170:952-5.

23 Wachtel SS, Elias S, Price J, Wachtel G, Phillips O, Shulman $\mathrm{L}$, et al. Fetal cells in the maternal circulation: isolation by multiparameter flow cytometry and confirmation by polymerase chain reaction. Hum Reprod 1991;6:1466-9.

24 Chakravarty A, Purandare H, Jaiswal GK, Gogate S, Soonawak RP. Prenatal diagnosis by circulating fetal cells in maternal blood. (A noninvasive technique of fetal diagnosis). Prenat Diagn 1992;12(Suppl):S66.

25 Lo YMD, Patel P, Sampietro M, Gillmer MDG, Fleming KA, Wainscoat JS. Detection of single-copy fetal DNA sequence from maternal blood. Lancet 1990;335: 1463-4.

26 Newton CR, Graham A, Heptinstall LE, Powell SJ, Summers C, Kalsheker N, et al. Analysis of any point mutation in DNA. The amplification refractory muta tion system (ARMS). Nucleic Acids Res 1989;17: 2503-16.

27 Chou O, Russell M, Birch DE, Raymond J, Bloch W. Prevention of pre-PCR mis-priming and primer dimerNucleic Acids Res 1992;20:1717-23.

28 Lo YMD, Wainscoat JS, Fleming KA. Non-invasive prenatal diagnosis. Lancet 1994;343:802-3.

29 Lo YMD, Bowell PJ, Selinger M, Mackenzie IZ, Chamberlain $\mathrm{P}$, Gillmer $\mathrm{MD}$, et al. Prenatal determina-
tion of fetal $\mathrm{RhD}$ status by analysis of peripheral blood of rhesus negative mothers. Lancet 1993;341:1147-8.

30 Lo YMD, Noakes L, Bowell PJ, Fleming KA, Wainscoat JS. Detection of fetal $\mathrm{RhD}$ sequence from peripheral blood of sensitised $\mathrm{RhD}$-negative pregnant women. $\mathrm{Br} F$ Haematol 1994;87:658-60.

31 Camaschella C, Alfarano A, Gottardi E, Travi M, Primignani P, Caligaris-Cappio F, et al. Prenatal diagnosis of fetal hemoglobin Lepore-Boston disease on maternal peripheral blood. Blood 1990;75:2102-6.

32 Lo YMD, Patel P, Baigent CN, Gillmer MD, Chamberlain $\mathrm{P}$, Travi $\mathrm{M}$, et al. Prenatal sex determination from maternal peripheral blood using the polytion from maternal peripheral blood using the

33 Higuchi R, Krummel B, Saiki RK. A general method of in vitro preparation and specific mutagenesis of DNA fragments: study of protein and DNA interactions. Nucleic Acids Res 1988;16:7351-67.

34 Lo YMD, Roux E, Jeannet M, Chapuis B, Fleming KA, Wainscoat JS. Detection of chimaerism after bonemarrow transplantation using the double amplification refractory mutation system. $\mathrm{Br} \mathcal{F}$ Haematol 1993;85: 223-6.

35 Lo YMD, Patel P, Newton CR, Markham AF, Fleming KA, Wainscoat JS. Direct haplotype determination by double ARMS: specificity, sensitivity and genetic applidouble ARMS: specificity, sensitivity and
cations. Nucleic Acids Res 1991;19:3561-7.

36 Lo YMD, Fleming KA, Wainscoat JS. Strategies for the detection of autosomal fetal DNA sequence from maternal peripheral blood. Ann NY Acad Sci (in press)

37 Bianchi DW, Flint AF, Pizzimenti MF, Knoll JH, Latt SA. Isolation of fetal DNA from nucleated erythrocytes in maternal blood. Proc Natl Acad Sci USA 1990;87: 3279-83.

38 Price JO, Elias S, Wachtel SS, Klinger K, Dockter M, Tharapel A, et al. Prenatal diagnosis with fetal cells isolated from maternal blood by multiparameter flow cytometry. Am $\mathcal{F}$ Obstet Gynecol 1991;165:1731-7.

39 Bianchi DW, Zickwolf GK, Yih MC, Flint AF, Geifman $\mathrm{OH}$, Erikson MS, et al. Erythroid-specific antibodies enhance detection of fetal nucleated erythrocytes in maternal blood. Prenat Diagn 1993;13:293-300

40 Gänshirt-Ahlert D, Börjesson-Stoll R, Burschyk M, Dohr A, Garritsen HS, Helmer E, et al. Detection of fetal trisomies 21 and 18 from maternal blood using triple gradient and magnetic cell sorting. $\mathrm{Am} \mathcal{F}$ Reprod Immunol 1993;30:193-200.

41 Zheng YL Carter NP, Price CM, Colman SM, Milton PJ, Hackett GA, et al. Prenatal diagnosis from maternal blood: Simultaneous immunophenotyping and FISH of fetal nucleated erythrocytes isolated by negative magnetic cell sorting. F Med Genet 1993;30:1051-6.

42 Bianchi DW, Shuber AP, DeMaria MA, Fougner AC, Klinger KW. Fetal cells in maternal blood: determination of purity and yield by quantitative PCR. $A m \mathcal{F}$ Obstet Gynecol (in press).

43 Lo YMD, Morey AL, Wainscoat JS, Fleming KA. Culture of fetal erythroid cells from maternal peripheral blood. Lancet 1994;344:264-5.

44 Mueller UW, Hawes CS, Wright AE, Petropoulos A, DeBoni E, Firgaira FA, et al. Isolation of fetal trophoDeBoni E, Firgaira FA, et al. Isolation of fetal trophoLancet 1990;336:197-200.

45 Bruch JF, Metezeau D, Garcia-Fonknechten N, Richard $\mathrm{Y}$, Tricottet V, Hsi BL, et al. Trophoblast-like cells sorted from peripheral maternal blood using flow cytometry: a multiparametric study involving transmission electron microscopy and fetal amplification. Prenat Diagn 1991;11:787-98.

46 Yeoh SC, Sargent IL, Redman CWG, Wordsworth BP, Thein SL. Detection of fetal cells in maternal blood. Prenat Diagn 1990;11:117-23.

47 Weissman M, Ylinen K, Knuutila S. Fetal granulocytes in maternal venous blood detected in in situ hybridization. maternal venous blood detected in

48 Elias S, Price J, Dockter M, Wachtel S, Tharapel A, Simpson JL. First trimester prenatal diagnosis of trisomy 21 in fetal cells from maternal blood. Lancet 1992;340:1033.

49 Bianchi DW, Mahr A, Zickwolf GK, Houseal TW, Flint AF, Klinger KW. Detection of fetal cells with $47, \mathrm{XY},+21$ karyotype in maternal peripheral blood. Hum Genet 1992;90:368-70.

50 Thomas MR, Williamson R, Craft I, Yazdani N, Rodeck $\mathrm{CH}$. Y chromosome sequence DNA amplified from peripheral blood of women in early pregnancy. Lancet 1994;343:413-4.

51 Bianchi DW, Stewart JE, Garber MF, Lucotte G, Flint AF. Possible effect of gestational age on the detection of fetal nucleated erythrocytes in maternal blood. Prenat Diagn 1991;11:523-8.

52 Hsieh TT, Pao CC, Hor J, Kao SM. Presence of fetal cells in maternal circulation after delivery. Hum Genet 1993;92:204-5.

53 Bianchi DW, Sylvester S, Zickwolf GK, Demaria MA, Weil GJ, Geifman OH. Fetal stem-cells persist in maternal blood for decades postpartum [abstract]. $\mathrm{Am} \mathfrak{f} \mathrm{Hum}$ Genet 1993;53:A251.

54 Redman CWG. Platelets and the beginnings of preeclampsia. $N$ Engl $\mathcal{F}$ Med 1990;323:478-80.

55 Chua S, Wilkins T, Sargent I, Redman C. Trophoblast deportation in pre-eclamptic pregnancy. Br $\mathcal{F}$ Obstet Gynaecol 1991;98:973-9. 